\title{
PENGARUH PROFITABILITAS DAN KEBIJAKAN DIVIDEN TERHADAP NILAI PERUSAHAAN PADA PT ASTRA OTOPARTS, TBK YANG TERDAFTAR DI BURSA EFEK INDONESIA
}

\author{
Oleh: \\ Evelina Simatupang \\ S1 Akuntansi \\ Darwin Lie, Jubi, Ernest Grace
}

Abstraksi

Tujuan dari penelitian ini adalah untuk mengetahui gambaran profitabilitas, kebijakan dividen, dan nilai perusahaan serta pengaruh profitabilitas dan kebijakan dividen terhadap nilai perusahaan pada PT Astra Otoparts, Tbk yang Terdaftar di Bursa Efek Indonesia secara simultan dan parsial. Metode analisis yang digunakan dalam penelitian ini adalah metode analisis deskriptif kualitatif dan analisis deskriptif kuantitatif. Objek penelitian ini adalah PT Astra Otoparts, Tbk yang terdaftar di Bursa Efek Indonesia tahun 2006 sampai tahun 2015. Metode yang digunakan untuk analisis data dalam penelitian ini adalah uji asumsi klasik, analisis regresi linier berganda, koefisien korelasi, koefisien determinasi, dan uji hipotesis (uji $F$ dan uji t). Pengujian dilakukan dengan menggunakan bantuan program Sofware Statistical Product and Service Solution (SPSS) versi 20.0.

Hasil analisa dari regresi linier berganda yaitu: $\hat{Y}=152,765+4,279 \mathrm{X}_{1}-0,643 \mathrm{X}_{2}$. Hal ini menunjukkan bahwa profitabilitas mempunyai pengaruh positif dan kebijakan dividen mempunyai pengaruh negatif terhadap nilai perusahaan. Hasil kolerasi yaitu $r=0,877$ artinya hubungan antara profitabilitas dan kebijakan dividen dengan nilai perusahaan sangat kuat. Dari koefisien determinasi nilai perusahaan dapat dijelaskan oleh profitabilitas dan kebijakan dividen sebesar 77\% dan sisanya 23\% dijelaskan variabel atau faktor lain yang tidak dijelaskan dalam penelitian ini. Hipotesis penelitian $\mathrm{H}_{0}$ ditolak dengan tingkat signifikansi 0,006 lebih kecil dari $5 \%$ atau $0,006<0,05$, artinya profitabilitas dan kebijakan dividen secara simultan berpengaruh signifikan terhadap nilai perusahaan pada PT Astra Otoparts, Tbk yang terdaftar di Bursa Efek Indonesia.

Kata Kunci: Profitabilitas, Kebijakan Dividen dan Nilai Perusahaan

Abstraction

The purpose of this research are to identify the description of profitability, dividend policy and firm value and analyze the effect of profitability and dividend policy to the firm value on PT Astra Otoparts, Tbk listed in Indonesia Stock Exchange either simultanly or partially. Methods of analysis used in this study are descriptive analysis of qualitative methods and quantitative descriptive analysis. The object of this research is PT Astra Otoparts, Tbk listed in the Indonesia Stock Exchange from 2006 until 2015 with the criteria as much as 10 years. The method used for data analysis in this study is the classical assumption test, multiple linear regression analysis, the correlation coefficient of determination, and hypothesis test ( $F$ test and $t$ test). Testing is done with the help of Sofware Statistical Product and Service Solution (SPSS) version 20.0.

Result of analysis multiple linear regression that is $\hat{Y}=152,765+4,279 X_{1}-0,643 X_{2}$. This shows that profitability have a positive effect and dividend policy have a negative effect on the firm value. The test results of correlation is $r=0,877$ means that the relationship between the profitability and dividend policy with the firm value is very strong. From coefficient determination firm value can be explained by profitability and dividend policy mounted to $77 \%$, and the rest $23 \%$, is explained by other factors that are not discussed in this study. The research hypothesis $H_{0}$ is rejected with the significance level 0,006 is smaller than 5\% or 0,05, means that profitability and dividend policy simultanly have significant effect to the firm value on PT Astra Otoparts, Tbk listed in Indonesia Stock Exchange.

Keywords: Profitability, Dividend Policy and Firm Value

\section{A. PENDAhuluan}

\section{Latar Belakang Masalah}

Pada umumnya setiap perusahaan memiliki tujuan yang sama dalam hal mendapatkan laba perusahaan, mengalami pertumbuhan dan juga demi mempertahankan kelangsungan hidup perusahaan. Salah satu tujuan perusahaan adalah memaksimumkan kemakmuran pemegang saham dengan cara memaksimalkan nilai perusahaan.

Nilai perusahaan sangat penting karena mencerminkan kinerja keuangan yang dapat mempengaruhi penilaian para investor terhadap perusahaan. Dengan baiknya nilai perusahaan dan kinerja perusahaan baik, maka tingkat keyakinan calon investor akan bertambah. Salah satu rasio untuk mengukur nilai perusahaan adalah dengan menggunakan Price to Book Value (PBV). Makin tinggi rasio ini berarti pasar makin percaya akan prospek perusahaan tersebut.

Salah satu faktor yang mempengaruhi nilai perusahaan adalah profitabilitas. Rasio profitabilitas menunjukkan efektifitas atau kinerja perusahaan dalam menghasilkan tingkat keuntungan. Profitabilitas dalam penelitian ini diproksikan 
dengan Return On Equity (ROE). Faktor lain yang mempengaruhi nilai perusahaan ialah kebijakan dividen. Kebijakan tersebut dapat mengundang investor untuk membeli atau mempertahankan kembali saham perusahaan dengan mempertimbangkan pengembalian atas dana yang mereka investasikan dalam bentuk saham berupa dividen. Kebijakan dividen dalam penelitian ini diproksikan dengan Dividend Payout Ratio (DPR).

\section{Rumusan Masalah}

a. Bagaimana gambaran profitabilitas, kebijakan dividen dan nilai perusahaan pada PT Astra Otoparts, Tbk yang terdaftar di Bursa Efek Indonesia?

b. Bagaimana pengaruh profitabilitas dan kebijakan dividen terhadap nilai perusahaan pada PT Astra Otoparts, Tbk yang terdaftar di Bursa Efek Indonesia baik secara simultan maupun parsial?

\section{Tujuan Penelitian}

a. Untuk mengetahui gambaran profitabilitas, kebijakan dividen dan nilai perusahaan pada PT Astra Otoparts, Tbk yang terdaftar di Bursa Efek Indonesia.

b. Untuk mengetahui pengaruh profitabilitas dan kebijakan dividen terhadap nilai perusahaan pada PT Astra Otoparts, Tbk yang terdaftar di Bursa Efek Indonesia baik secara simultan maupun parsial.

\section{Metode Penelitian}

Dalam penelitian ini, penulis mengambil objek penelitian pada PT Astra Otoparts, Tbk yang terdaftar di Bursa Efek Indonesia dengan cara mengakses data dari situs www.idx.co.id.

Adapun desain penelitian yang digunakan dalam penulisan skripsi ini adalah penelitian kepustakaan (library research). Teknik pengumpulan data yang dilakukan penulis dalam penelitian ini adalah dokumentasi. Adapun jenis data yang digunakan dalam penelitian ini adalah jenis data kualitatif dan data kuantitatif. Hasil data yang diperoleh akan dianalisis secara deskriptif baik bersifat kualitatif dan kuantitatif.

\section{B. LANDASAN TEOR}

\section{Laporan Keuangan}

Menurut Kasmir (2010:66), laporan keuangan adalah laporan yang menunjukkan informasi akuntansi yang terdapat pada laporan keuangan untuk membuat keputusan yang cerdas, manajer membutuhkan untuk mengoperasikan bisnis secara efisien dan badan perpajakan membutuhkannya untuk menilai pajak dengan cara wajar.

Menurut Rudianto (2012:17), sesuai dengan Standar Akuntansi Keuangan yang berlaku di Indonesia, laporan keuangan terdiri dari:

a. Laporan Laba Rugi Komprehensif (Statement of Comprehensif Income), yaitu laporan yang menunjukan kemampuan perusahaan dalam menghasilkan laba selama suatu periode akuntansi atau satu tahun.

b. Laporan Perubahan Ekuitas (Statement of Changes in Equity) adalah laporan yang menunjukan perubahan hak residu atas aset perusahaan setelah dikurangi semua kewajiban.

c. Laporan Posisi Keuangan (Statement of Financial Position) adalah daftar yang menunjukan posisi sumber daya yang dimiliki perusahaan, serta informasi dari mana sumber daya tersebut diperoleh.

d. Laporan Arus Kas (Statement of Cash Flows) adalah laporan yang menunjukan aliran uang yang diterima dan yang digunakan perusahaan selama satu periode akuntansi, beserta sumbersumbernya.

e. Catatan atas Laporan Keuangan adalah informasi tambahan yang harus diberikan menyangkut berbagai hal yang terkait secara langsung dengan laporan keuangan yang disajikan entitas tertentu, seperti kebijakan akuntansi yang digunakan perusahaan, dan berbagai informasi yang relevan dengan laporan keuangan tersebut.

\section{Analisis Laporan Keuangan}

Menurut Subramanyam dan John (2010:130), analisis laporan keuangan (financial statement analysis) adalah aplikasi dari alat dan teknik analitis untuk laporan keuangan bertujuan untuk menghasilkan estimasi dan kesimpulan yang bermanfaat dalam analisis bisnis.

Dalam menganalisis laporan keuangan dan menilai posisi keuangan atau kemajuan-kemajuan yang dialami perusahaan, faktor utama yang mendapatkan perhatian oleh penganalisa adalah rasio keuangan. Melalui rasio keuangan perusahaan dapat melihat risiko maupun kesempatan yang dimiliki perusahaan. Menurut Kasmir (2010:104), rasio keuangan adalah kegiatan membandingkan angkaangka yang ada dalam laporan keuangan dengan cara membagi satu angka dengan angka lainnya.

Menurut Brigham dan Joel (2010:134), bahwa rasio keuangan yang sering digunakan untuk memprediksi harga saham yang dikelompokkan dalam lima kelompok yaitu:

a. Rasio Likuiditas

Rasio Likuiditas adalah rasio yang menunjukkan hubungan antara kas dan aset lancar lainnya dari sebuah perusahaan dengan kewajiban lancarnya. Rasio ini terdiri dari current ratio, acid test ratio, dan cash ratio.

b. Rasio Manajemen Aset

Serangkaian rasio yang mengukur seberapa efektif perusahaan telah mengelola aset-asetnya. Rasio ini terdiri dari inventory turnover ratio, days sales outstanding, fixed asset turnover ratio, dan total asset turnover ratio.

c. Rasio Manajemen Utang

Rasio manajemen utang atau rasio leverage keuangan adalah rasio yang menunjukkan dana melalui utang. Rasio ini terdiri atas debt to total 
asset, debt to total equity, times interert earned, dan rasio cakupan beban tetap.

d. Rasio Profitabilitas

Rasio profitabilitas adalah sekelompok rasio yang menunjukkan gabungan efef-efek dari likuiditas, manajemen aktiva, dan utang pada hasil-hasil operasi. Rasio ini terdiri dari net profit margin, basic earning power, return on asset dan return on equity.

e. Rasio Nilai Pasar

Rasio nilai pasar adalah sekumpulan rasio yang menghubungkan harga saham perusahaan laba, arus kas, dan nilai buku per lembar sahamnya. Rasio ini terdiri dari price earning ratio, price cashflow ratio, book value per share, earning per share, dan dividend per share.

\section{Profitabilitas}

Menurut Sudana (2011:22), profitabilitas adalah rasio untuk mengukur kemampuan perusahaan untuk menghasilkan laba dengan menggunakan sumber-sumbernya yang dimiliki perusahaan, seperti aktiva, modal, atau penjualan perusahaan.

Menurut Sudana (2011:22), rasio-rasio yang termasuk dalam rasio profitabilitas adalah:

a. Return On Asset (ROA), menunjukkan kemampuan perusahaan dengan menggunakan seluruh aktiva yang dimilki untuk menghasilkan laba setelah pajak. $\mathrm{ROA}=\frac{\text { Laba Bersih Setelah Pajak }}{\text { Iumlah aktiva perusahaan }} \mathrm{x}$ $100 \%$

b. Basic Earning Power (BEP), digunakan untuk mengukur kemampuan di perusahaan untuk menghasilkan laba sebelum bunga dan pajak dengan menggunakan total aset yang dimiliki perusahaan.

Basic Earning Power $=\frac{\text { Laba Sebelum Pajak }}{\text { Total Aset }}$

c. Return On Equity (ROE), merupakan sebuih rasio yang dipergunakan oleh pemegang saham untuk menilai kinerja perusahaan yang bersangkutan, serta digunakan untuk mengukur tingkat pengambilan modal dari perusahaan. $\mathrm{ROE}=\frac{\text { Laba Bersih Setelah Pajak }}{\text { Modal Sendiri }} \times \mathbf{1 0 0} \%$

d. Net Margin atau Profit Margin On Sales, merupakan salah satu rasio yang digunakan untuk mengukur margin laba atas penjualan. Rasio ini mengukur kemampuan perusahaan untuk menghasilkan laba dengan menggunakan penjualan yang dicapai perusahaan.

Profit margin $=$ Penjualan Bersih - Harga Pokok Penjualan

Dalam penelitian ini, parameter profitabilitas yang digunakan adalah Return On Equity (ROE) yaitu persentase atau perbandingan antara laba bersih setelah pajak dengan ekuitas. Pemilihan ROE sebagai proksi dari profitabilitas adalah karena dalam ROE ditunjukkan, semakin tinggi ROE menunjukkan semakin efisien perusahaan dalam menggunakan modal sendiri untuk menghasilkan laba investor yang ditanam pada perusahaan.

\section{Kebijakan Dividen}

Menurut Halim (2007:16), dividen adalah pembagian keuntungan yang diberikan emiten kepada pemegang sahamnya. Menurut Rudianto (2009:309), ada beberapa jenis-jenis dividen yang dapat dibagikan oleh perusahaan kepada pemegang sahamnya sebagai berikut:

a. Dividen Kas (Cash Dividend), adalah bagian dari laba usaha yang dibagikan kepada para pemegang sahamnya dalam bentuk uang tunai.

b. Dividen Harta (Property Dividend), adalah bagian dari laba suatu perusahaan yang dibagikan dalam bentuk harta selain kas. Walaupun dalam bentuk harta lain tetapi biasanya harta tersebut dalam bentuk surat berharga yang dimiliki oleh perusahaan tersebut.

c. Dividen Skrip atau Dividen Hutang, adalah bagian dari laba usaha perusahaan yang dibagikan kepada pemegang saham dalam bentuk janji tertulis untuk membayar sejumlah uang di masa mendatang.

d. Dividen Saham, adalah bagian dari laba usaha yang ingin dibagikan kepada pemegang saham dalam bentuk saham baru perusahaan itu sendiri.

e. Dividen Likuiditas, adalah aktiva yang ingin dibayarkan oleh perusahaan kepada pemegang sahamnya dalam berbagai bentuknya tetapi tidak didasarkan kepada besarnya laba usaha atau saldo laba ditahan perusahaan.

Menurut Sartono (2008:281), kebijakan dividen adalah keputusan apakah laba yang diperoleh perusahaan akan dibagikan kepada pemegang saham sebagai dividen atau ditahan dalam bentuk laba ditahan guna pembiayaan investasi dimasa yang akan datang. Kebijakan dividen adalah keputusan apakah yang diperoleh perusahaan akan dibagikan kepada pemegang saham dalam bentuk dividen atau sebagai saldo laba untuk menambah modal guna pembiayaan investasi di masa yang akan datang.

Menurut Astuti (2004:147), tipe-tipe kebijakan dividen adalah:

a. Kebijakan dividen dengan persentase tetap pembayaran dividen tunai. Kebijakan dividen dengan nama Dividend Payout Ratio (DPR).

Rumus dividend payout ratio adalah sebagai berikut:

$\mathrm{DPR}=\stackrel{\text { Dividen Tunai per lembar }}{ }$

Laba per lembar

b. Kebijakan dividen biasa

Pada kebijakan dividen biasa atau regular dividend policy, perusahaan membayar dividen per lembar saham dalam jumlah rupiah yang tetap setiap periode.

c. Kebijakan dividen rendah plus ekstra

Menurut kebijakan ini perusahaan membayar dividen tunai secara rutin setiap periode dalam jumlah yang tetap, jika laba perusahaan periode yang bersangkutan sangat baik maka jumlah pembayaran tetap tersebut akan ditambah pembayaran dividen ekstra.

Dalam penelitian ini penulis menggunakan Dividend Payout Ratio (DPR) sebagai parameter kebijakan dividen yaitu, dividen tunai yang 
dibayarkan dan dibagi dengan laba bersih setelah pajak. Pada hakikatnya. Dividend Payout Ratio (DPR) adalah menentukan porsi keuntungan yang akan dibagikan kepada para pemegang saham, dan yang akan datang sebagai bagian dari laba ditahan.

\section{Nilai Perusahaan}

Nilai perusahaan diciptakan oleh perusahaan melalui kegiatan perusahaan dari waktu ke waktu agar mencapai nilai perusahaan yang maksimum di atas nilai buku. Menurut Keown et. al (2004:470), nilai perusahaan merupakan nilai pasar atas surat berharga, hutang, dan ekuitas perusahaan yang beredar. Indikator dari nilai perusahaan adalah harga saham.

Menurut Subramanyam dan John (2005:43), ukuran nilai pasar perusahaan dalam beberapa literature yang berdasarkan harga saham dapat diukur dengan:

a. Rasio harga terhadap laba (Price to Earning Ratio) adalah rasio yang membandingkan antara harga pasar perlernbar saham dengan laba persaham.

Price to Earning Ratio $=\stackrel{\text { Harga Pasar Per lembar Sahan }}{ }$

b. Imbal hasil dividen (Dividen Yield) adalah sasio yang membandingkan antara dividen tunai persaham dengan harga pasar per lembar saham. Bentuk rumusini adalah:

Dividend Yield $=-\frac{\text { Dividen Tunai Per Saham }}{\text { Harga Pasar Per Lembar Saham }}$

c. Tingkat pembayaran dividen (dividend payou rate) ialah rasio yang membandingkan antara dividen tunai persaham dengan laba per saham. Bentuk rumus ini adalah:

Dividend Payout Rate $=$ Dividen Tunai Persaham

d. Harga terhadap nilai buku (Price to Book) ialah rasio yang menbandingkan antara harga pasar per lembar saham dengan nilai buku per lembar saham. Bentuk rumus ini adalah:

Price to Book Value $=\frac{\text { Hara Pasar Per Lembar Saham }}{\text { Nitai Buku Per Lembar Saham }}$

Dalam penelitian ini nilai perusahaan dapat diukur yang salah satunya adalah Price to Book Value (PBV). Price to Book Value merupakan perbandingan antara nilai saham menurut pasar dengan nilai buku ekuitas perusahaan. Nilai buku dihitung sebagai hasil antara ekuitas pemegang saham dengan jumlah saham yang beredar. Rasio harga saham terhadap nilai buku perusahaan atau PBV, menunjukkan tingkat kemampuan perusahaan menciptakan nilai relatif terhadap jumlah modal.

\section{Pengaruh Profitabilitas dan Kebijakan} Dividen Terhadap Nilai Perusahaan

Profitabilitas dihitung dengan Return On Equity (ROE). Menurut Brigham dan Joel (2010:150), bahwa Return On Equity (ROE) mencerminkan pengaruh dari seluruh rasio lain dan merupakan ukuran kinerja tunggal yang terbaik dilihat dari kacamata akuntansi. Investor sudah pasti menyukai nilai ROE yang tinggi, dan ROE yang tinggi umumnya memiliki korelasi positif dengan harga saham yang tinggi. Apabila kemampuan perusahaan untuk menghasilkan laba meningkat, maka harga saham juga akan meningkat. Dengan meningkatnya harga saham maka nilai perusahaan ikut meningkat.

Selain karena Profitabilitas faktor yang mempengaruhi nilai perusahaan adalah Kebijakan Dividen. Kebijakan dividen yang optimal pada suatu perusahaan adalah kebijakan yang menciptakan keseimbangan diantara dividen saat ini dan pertumbuhan di masa mendatang sehingga memaksimumkan harga saham. Menurut Astuti (2004:145), kebijakan dividen menyangkut keputusan untuk membagi laba atau menahannya guna diinvestasikan kembali di dalam perusahaan.

\section{PEMBAHASAN}

\section{Analisa}

\section{a. Uji Asumsi Klasik}

Uji normalitas dengan pengujian One Sample Kolmogorov-Smirnov diperoleh nilai Asymp Sig. (2tailed) sebesar 0,902 yang berarti nilai tersebut di atas nilai signifikan 0,902>0,05. Dengan demikian dapat dikatakan bahwa variabel residual berdistribusi normal. Untuk uji multikolineritas, menunjukkan bahwa variabel profitabilitas dan kebijakan dividen semuanya tidak terjadi multikolineritas karena nilai tolerance berada di atas 0,10 dan nilai VIF berada di bawah 10 .

Dari grafik scatterplot terlihat bahwa plot menyebar secara acak di atas maupun di bawah angka nol pada sumbu Regression Studentized Residual. Oleh karena itu, maka berdasarkan uji heteroskedastisitas menggunakan metode analisis grafik, pada model regresi yang terbentuk dinyatakan tidak terjadi gejala heteroskedastisitas. Nilai DurbinWatson dalam penelitian ini adalah sebesar 2,633. Berdasarkan tabel Durbin-Watson diketahui bahwa nilai dL untuk data sebanyak 10 dan $\mathrm{k}=2$ adalah sebesar 0,6972 sehingga 4-dL=3,3028 dan nilai $\mathrm{dU}$ sebesar 1,6413 sehingga 4-dU=2,3587. Dengan demikian nilai DW sebesar 2,633 berada diantara nilai du < DW < 4-dU atau 1,6413 < 2,633 < 2,3587 sehingga dapat disimpulkan tidak ada gejala autokorelasi.

\section{b. Deskriptif Kualitatif}

Analisis deskriptif dalam penelitian ini bertujuan untuk mendapatkan gambaran atau deskripsi mengenai profitabilitas, kebijakan dividen dan nilai perusahaan pada PT Astra Otoparts,Tbk yang terdaftar di Bursa Efek Indonesia periode 20062015.

1) Profitabilitas pada PT Astra Otoparts, Tbk yang Terdaftar di Bursa Efek Indonesia periode 2006-2015

Dari hasil penelitian, diketahui nilai maksimum dari profitabilitas yang diukur dengan ROE pada PT Astra Otoparts, Tbk yang terdaftar di Bursa Efek Indonesia periode 2006-2015 yaitu 
sebesar 27,81\% terjadi pada tahun 2010. Nilai minimum ROE terjadi pada tahun 2015, yaitu sebesar 3,18\%. Nilai rata-rata ROE sebesar $17,76 \%$, artinya setiap Rp 100,00 ekuitas menghasilkan laba sebesar Rp 17,76

Tingginya nilai Return On Equity (ROE) menunjukkan penilaian atau harapan yang baik bag para investor terhadap perusahaan. Semakin tinggi rasio ini, akan memberikan prospek yang baik bagi pihak manajemen perusahaan dan para investor atau bagi pihak di luar perusahaan, terutama pihak-pihak yang memiliki hubungan atau kepentingan dengan perusahaan.

\section{2) Kebijakan Dividen pada PT Astra Otoparts, Tbk yang terdaftar di Bursa Efek Indonesia Periode 2006-2015}

Dari hasil penelitian, diketahui nilai rata-rata kebijakan dividen yang diproksikan oleh Dividen Payout Ratio (DPR) pada PT Astra Otoparts, Tbk yang terdaftar di Bursa Efek Indonesia periode 20062015 yaitu sebesar 42,40\%, artinya setiap Rp 100,00 laba setelah pajak dibagikan sebagai dividen yang sebesar Rp 42,40 kepada pemegang saham biasa. Nilai maksimum DPR berada pada tahun 2015 sebesar $87,88 \%$. Nilai Minimum DPR berada pada tahun 2007 sebesar 15,25\%

\section{3) Nilai Perusahaan pada PT Astra Otoparts, Tbk yang terdaftar di Bursa Efek Indonesia Periode 2006-2015}

Dari hasil penelitian, diketahui nilai perusahaan PT Astra Otoparts, Tbk yang terdaftar di Bursa Efek Indonesia periode 2006-2015 yang diproksikan dengan Price to Book Value (PBV) memiliki rata-rata sebesar 132,03 , artinya setiap $\mathrm{Rp}$

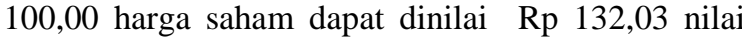
pasar. Nilai maksimum PBV sebesar 266,23\% berada pada tahun 2011. Peningkatan ini disebabkan meningkatnya harga saham perusahaan. Hal ini berarti nilai PBV yang tinggi maka akan menunjukkan besarnya harga saham dibandingkan nilai buku per sahamnya. Nilai minimum PBV perusahaan sebesar $19,50 \%$ berada pada tahun 2008 .

\section{c. Deskriptif Kuantitatif}

\section{1) Analisis Regresi Linier Berganda}

Berdasarkan hasil analisa dengan program SPSS, maka model regresi linear berganda yaitu sebagai berikut : $\hat{Y}=152,765+4,279 X_{1}-0,643 X_{2}$

Berdasarkan hasil persamaan regresi di atas maka dapat disimpulkan bahwa profitabilitas berpengaruh positif dan kebijakan dividen berpengaruh negatif terhadap nilai perusahaan pada PT Astra Otoparts, Tbk yang terdaftar di Bursa Efek Indonesia Periode 2006 sampai dengan tahun 2015.

\section{2) Analisa Korelasi dan Determinasi}

Berdasarkan hasil pengolahan data SPSS diperoleh nilai koefisien korelasi adalah sebesar 0,877 . Dengan demikian dapat dikatakan bahwa korelasi atau hubungan antara profitabilitas dan kebijakan dividen terhadap nilai perusahaan pada PT Astra Otoparts, Tbk yang terdaftar di Bursa Efek Indonesia adalah sangat kuat.

Untuk nilai koefisien determinasi adalah sebesar 0,770 yang berarti bahwa nilai perusahaan dapat dijelaskan oleh profitabilitas dan kebijakan dividen sebesar $77 \%$ pada PT Astra Otoparts, Tbk periode 2006-2015 dan sisanya 23\% dijelaskan oleh variabel atau faktor lain yang tidak diteliti pada penelitian ini, seperti quick rasio, cash rasio, return on asset, dan profit margin ratio.

\section{3) Uji Hipotesis}

a) Uji Simultan (Uji F)

Uji statistik $\mathrm{F}$ pada dasarnya menunjukkan apakah semua variabel independen yang dimasukkan dalam model mempunyai pengaruh secara simultan terhadap variabel dependen.

Uji ini dilakukan dengan membandingkan signifikansi $F_{\text {hitung }}$ dengan $F_{\text {tabel }}$ dengan ketentuan sebagai berikut:

(1) Jika $F_{\text {hitung }}>F_{\text {tabel }}$ dan nilai probabilitas $<0,05$ maka $\mathrm{H}_{0}$ ditolak, yang berarti profitabilitas dan kebijakan dividen secara silmultan berpengaruh signifikan terhadap nilai perusahaan.

(2) Jika $F_{\text {hitung }}<\mathrm{F}_{\text {tabel }}$ dan nilai probabilitas $>0,05$ maka $\mathrm{H}_{0}$ diterima, yang berarti bahwa profitabilitas dan kebijakan dividen secara silmultan berpengaruh tidak signifikan terhadap nilai perusahaan.

Dari hasil pengolahan data, dapat dilihat bahwa dengan tingkat kepercayaan $95 \%$, n-k-1=102-1=7, diperoleh angka $F_{\text {tabel }}$ sebesar 4,74 dan besar $F_{\text {hitung }}$ adalah 11,038. Karena $F_{\text {hitung }}>F_{\text {tabel }}$ atau $11,038>4,74$ maka $\mathrm{H}_{0}$ ditolak dan untuk tingkat signifikansi adalah $0,006<0,05$, maka keputusan yang diambil adalah profitabilitas dan kebijakan dividen secara silmultan berpengaruh signifikan terhadap nilai perusahaan pada PT Astra Otoparts, Tbk yang terdaftar di Bursa Efek Indonesia.

\section{b) Uji Parsial (Uji t)}

Uji $\mathrm{t}$ digunakan untuk menguji pengaruh variabel bebas terhadap variabel terikat secara parsial atau individual. Adapun hipotesis yang diuji adalah sebagai berikut :

(1) $\mathrm{H}_{0}$ ditolak jika $t_{\text {hitung }}>t_{\text {tabel }}$, artinya profitabilitas dan kebijakan dividen secara parsial berpengaruh signifikan terhadap nilai perusahaan.

(2) $\mathrm{H}_{0}$ diterima jika $t_{\text {hitung }}<\mathrm{t}_{\text {tabel }}$, artinya profitabilitas dan kebijakan dividen secara parsial berpengaruh tidak signifikan terhadap nilai perusahaan.

Hipotesis digunakan untuk menguji signifikansi koefisien persamaan regresi dirumuskan sebagai berikut :

(1) Jika $t_{\text {hitung }}>t_{\text {tabel }}$ atau probabilitas signifikan $<\alpha$ (5\%), maka $\mathrm{H}_{0}$ ditolak.

(2) Jika $t_{\text {hitung }}<\mathrm{t}_{\text {tabel }}$ atau probabilitas signifikan $>\alpha$ (5\%), maka $\mathrm{H}_{0}$ diterima. 

berikut:

Dari hasil uji t diperoleh kesimpulan sebagai

(1) Untuk variabel profitabilitas dengan tingkat kepercayaan $95 \%$, n-k-1=10-2- $1=7$ dan $\alpha=5 \%$, dari tabel $t$ diperoleh angka $t_{\text {tabel }}$ sebesar 2,3646 dan besar $t_{\text {hitung }}$ adalah 1,737 . Karena $t_{\text {hitung }}<$ $\mathrm{t}_{\text {tabel }}$ atau $1,737<2,3646$ maka $\mathrm{H}_{0}$ diterima dan untuk tingkat signifikansi adalah $0,126>0,05$, maka keputusan yang diambil adalah profitabilitas secara parsial berpengaruh tidak signifikan terhadap nilai perusahaan pada PT Astra Otoparts, Tbk.

(2) Untuk variabel kebijakan dividen dengan tingkat kepercayaan 95\%, n-k-1=10-2-1=7 dan $\alpha=5 \%$, dari tabel $\mathrm{t}$ diperoleh angka $\mathrm{t}_{\text {tabel }}$ sebesar 2,3646 dan besar $t_{\text {hitung adalah 4,738. Karena }}$ $\mathrm{t}_{\text {hitung }}>\mathrm{t}_{\text {tabel }}$ atau 4,738>2,3646 maka $\mathrm{H}_{0}$ ditolak dan untuk tingkat signifikansi adalah $0,002<0,05$, maka keputusan yang diambil adalah kebijakan dividen secara parsial berpengaruh signifikan terhadap nilai perusahaan pada PT Astra Otoparts, Tbk yang terdaftar di Bursa Efek Indonesia.

\section{Evaluasi}

a. Profitabilitas pada PT Astra Otoparts, Tbk yang Terdaftar di Bursa Efek Indonesia

Dari hasil penelitian ini, menunjukkan kondisi profitabilitas PT Astra Otoparts, Tbk periode 2006-2015 yang diukur dengan menggunakan Return On Equity (ROE) mengalami fluktuasi dan cenderung menurun. Dimana Return On Equity (ROE) minimum sebesar 3,18\% berada pada tahun 2015 dan dibawah rata-rata berada pada tahun 2006, 2013, dan 2014. Penurunan ini disebabkan meningkatnya jumlah ekuitas sedangkan laba setelah pajak mengalami penurunan. Hal ini meyebabkan perusahaan mendapatkan laba yang semakin kecil. Oleh karena itu, perusahaan perlu meningkatkan penjualan untuk mendapatkan laba yang maksimal. Selain itu jika peningkatan penjualan tidak dapat dicapai, maka penggunaan modal ekuitas perlu dikurangi.

\section{b. Kebijakan Dividen pada PT Astra Otoparts,} Tbk yang Terdaftar di Bursa Efek Indonesia

Berdasarkan hasil penelitian, diperoleh ratarata dividen payout ratio pada PT Astra Otoparts, Tbk yang terdaftar di Bursa Efek Indonesia adalah sebesar $42,40 \%$. Hal ini menunjukkan bahwa tingkat pembayaran dividen sebesar $42,40 \%$ dan sisanya diinvestasikan kembali untuk masa yang akan datang. Dimana dapat dilihat pada tabel 13 terdapat 6 tahun nilai dividen payout ratio perusahaan yang berada di atas rata-rata nilai dividen payout ratio yaitu pada tahun 2008, 2010, 2011, 2013 sampai 2015 dan terdapat 4 tahun nilai DPR perusahaan yang berada di bawah rata-rata nilai dividen payout ratio yaitu tahun 2006, 2007, 2009 dan 2012.

Dengan begitu dapat dilihat bahwa pembayaran dividen yang dibagikan belum dapat dikatakan baik karena tingkat pembayaran dividen pada PT Astra Otoparts, Tbk yang terdaftar di Bursa Efek Indonesia masih tergolong rendah.

\section{c. Nilai Perusahaan pada PT Astra Otoparts,} Tbk yang Terdaftar di Bursa Efek Indonesia

Dari hasil penelitian, menunjukkan kondisi nilai perusahaan PT Astra Otoparts, Tbk periode 2006-2015 yang diukur dengan menggunakan Price to Book Value (PBV) mengalami fluktuasi cenderung menurun. Dimana price to book value (PBV) minimum sebesar $19,50 \%$ berada pada tahun 2008 dan di bawah rata-rata berada ada tahun 2006, 2007, 2009, 2013 sampai 2015. Penurunan disebabkan oleh turunnya harga saham akibatnya pandangan investor terhadap perusahaan kurang baik. Hal ini berarti bahwa perusahaan tersebut dihargai lebih rendah dari nilai bukunya atau dapat dikatakan tingkat kepercayaan para investor untuk menanamkan modalnya lebih rendah dari nilai rata-ratanya.

d. Pengaruh Profitabilitas dan Kebijakan

Dividen Terhadap Nilai Perusahaan pada PT

Astra Otoparts, Tbk yang Terdaftar di Bursa Efek Indonesia

Berdasarkan hasil analisis regresi berganda yang telah dilakukan, diketahui bahwa Profitabilitas yang diukur dengan Return On Equity (ROE) berpengaruh positif terhadap nilai perusahaan. Hal ini dapat dilihat dari persamaan regresi yaitu: $\hat{Y}=$ $152,765+4,279 \mathrm{X}_{1}-0,643 \mathrm{X}_{2}$ Hal ini menunjukkan dengan meningkatnya harga saham maka nilai perusahaan ikut meningkat. Kebijakan Dividen yang diukur dengan Dividen Payout Ratio (DPR) berpengaruh negatif terhadap nilai perusahaan. Besar pengaruh yang dimaksud adalah $-0,643$ yang berarti bahwa setiap variabel kebijakan dividen meningkat besar satu satuan, maka nilai perusahaan akan menurun sebesar -0,643 dengan asumsi variabel independen lainnya dianggap tetap atau sama dengan nol.

Berdasarkan hasil regresi di atas bahwa kebijakan dividen berpengaruh negatif terhadap nilai perusahaan. Hal ini tidak sesuai dengan teori Sudana (2011:169), yang menyatakan bahwa kebijakan dividen berpengaruh positif terhadap harga saham, jika deviden yang tinggi maka harga pasar saham meningkat serta nilai perusahaan juga meningkat.

\section{KESIMPULAN DAN SARAN}

\section{Kesimpulan}

a. Rata-rata profitabilitas yang diproksikan dengan Return On Equity (ROE) yaitu sebesar $17,76 \%$. Untuk kebijakan dividen yang diproksikan dengan Dividen Payout Ratio (DPR) memiliki nilai rata-rata yaitu sebesar $42,40 \%$. Sedangkan rata-rata nilai perusahaan yang diukur dengan menggunakan Price to Book Value (PBV) pada PT Astra Otoparts, Tbk yang terdaftar di Bursa Efek Indonesia periode 2006-2015 adalah sebesar $132,03 \%$.

b. Dari hasil pengujian regresi linear berganda diketahui bahwa profitabilitas mempunyai 
pengaruh positif dan kebijakan dividen mempunyai pengaruh negatif terhadap nilai perusahaan. Hal ini dapat dilihat dari persamaan regresi yaitu $\hat{Y}=152,765+4,279 X_{1}-0,643 X_{2}$.

c. Dari uji koefisien korelasi diperoleh hasil bahwa terdapat korelasi atau hubungan yang sangat kuat antara profitabilitas dan kebijakan dividen dengan nilai perusahaan. Sementara untuk uji koefisien determinasi diperoleh hasil bahwa nilai perusahaan dapat dijelaskan oleh profitabilitas dan kebijakan dividen yaitu sebesar $77 \%$, sisanya sebesar $23 \%$ dijelaskan oleh variabel lain yang tidak diteliti dalam penelitian ini seperti quick ratio, cash ratio, return on asset, dan profit margin ratio.

d. Dari hasil uji statistik $F$ diperoleh hasil $F_{\text {hitung }}>$ $\mathrm{F}_{\text {tabel }}$ atau 11,693 > 4,74 maka $\mathrm{H}_{0}$ ditolak dan untuk tingkat signifikansi adalah 0,006 $<0,05$, maka keputusan yang diambil adalah profitabilitas dan kebijakan dividen secara simultan berpengaruh signifikan terhadap nilai perusahaan.

e. Dari hasil uji statistik t diperoleh hasil bahwa secara parsial untuk variabel profitabilitas : $t_{\text {hitung }}$ $<\mathrm{t}_{\text {tabel }}$ yaitu $1,737<2,3646$ dan tingkat signifikan 0,126 > 0,05 yang berarti profitabilitas secara parsial berpengaruh tidak signifikan terhadap nilai perusahaan. Sementara untuk variabel kebijakan dividen diketahui bahwa $t_{\text {hitung }}$ $>\mathrm{t}_{\text {tabel }}$ yaitu $4,738>2,3646$ dan tingkat signifikansi $0,002<0,05$ yang berarti bahwa kebijakan dividen secara parsial berpengaruh signifikan terhadap nilai perusahaan.

\section{Saran}

a. PT Astra Otoparts, Tbk sebaiknya meningkatkan profitabilitas perusahaan dengan cara mengurangi biaya yang tidak diperlukan, mencari pemasok yang lebih murah serta melakukan peningkatan volume penjualan untuk menghasilkan laba atau pendapatan perusahaan, melakukan kontrak berkala terhadap efektivitas kinerja dengan memberikan pelatihan khusus pada karyawan terbaik.

b. PT Astra Otoparts, Tbk sebaiknya meningkatkan dividen perusahaan karena dividen salah satu faktor investor tertarik untuk membeli saham dan investasi kembali.

c. PT Astra Otoparts, Tbk sebaliknya meningkatkan laba dengan modal perusahaan maupun modal para investor melalui hasil penjualan yang mana dengan laba yang tinggi lebih disukai oleh para investor sehingga secara tidak langsung harga saham perusahaan meningkat.

d. Karena keterbatasan penulisan dalam penelitian ini, penulis menyadari bahwa masih terdapat kelemahan dan belum mengungkapkan seluruh variabel yang dapat mempengaruhi, maka diharapkan bagi peneliti selanjutnya, untuk melakukan penelitian ini lebih lanjut pada variabel-variabel lain yang belum dimasukkan dalam penelitian yang mempengaruhi nilai perusahaan seperti Return On Asset (ROA), Net Profit Margin (NPM), Gross Profit Margin (GPM), Debt to Asset Ratio (DAR), dan juga mempertimbangkan faktor lain seperti keputusan investasi, keputusan pendanaan, dan keputusan manajemen aset serta memperluas objek penelitian, sehingga dapat diketahui pengaruh profitabilitas dan kebijakan dividen terhadap nilai perusahaan pada perusahaan lain dan membuat perbandingan.

\section{E. DAFTAR PUSTAKA}

Astuti, Dewi. 2004. Manajemen Keuangan Perusahaan. Jakarta: Penerbit Ghalia Indonesia.

Brigham, Eugene F. dan Joel F. Houston. 2010. Dasar-dasar Manajemen Keuangan: Essensial of Financial Management, Edisi 11, Buku 1. Jakarta: Salemba Empat.

Halim, Abdul. 2007. Manajemen Keuangan Bisnis. Bogor: Ghalia Indonesia.

Kasmir. 2010. Pengantar Manajemen Keuangan. Edisi Pertama, Cetakan Pertama. Jakarta: Kencana.

Keown, et.al. 2004. Manajemen Keuangan: Prinsip-prinsip dan Aplikasi. Edisi Kesembilan, Jilid 1. Jakarta: PT Indeks Kelompok Gramedia.

Rudianto. 2009. Pengantar Akuntansi. Jakarta.: Penerbit Erlangga.

2012. Pengantar Akuntansi. Adaptasi IFRS. Jakarta: Erlangga.

Sartono, Agus. 2008. Manajemen Keuangan. Edisi Keempat. Yogyakarta : BPFE.

Subramanyam, K. R and Jhon J. Wild, 2010, Analisis Laporan Keuangan: Financial Statement Analysis, Buku Satu, Edisi Sepuluh, Jakarta: Salemba Empat 